\title{
The Role of Religiosity to Purchase Decision of Halal Cosmetics in Youth
}

\author{
Leni Susanti ${ }^{1}$, Muhammad Yusuf ${ }^{2}$ \\ \{lenisusanti2612@gmail.com ${ }^{1}$ \}
}

\begin{abstract}
Department of Management, Universitas Muhammadiyah Pekajangan Pekalongan, Indonesia ${ }^{1}$ Department of Accounting, Universitas Muhammadiyah Pekajangan Pekalongan, Indonesia ${ }^{2}$
\end{abstract}

\begin{abstract}
In Islam, halal refers to what is allowed, while haram refers to what is forbidden. The word halal is frequently connected with food. However, this phrase encompasses more than just food. This is also true when it comes to cosmetics. This study is going to investigate the effect of religiosity on to purchase decision of halal cosmetics in youth. The method used for this research is quantitative. The analytical tool used in SmartPLS 3.2.0. The sample in this research amounted to 100 respondents from 3 faculties in UMPP. The result of this research indicates that religiosity affects purchase decisions. Even though religiosity affects purchase decision but youth does not matter about the halalness of the cosmetics they buy due to the understanding that halal is only something that is eaten. It implies that young consumers of halal cosmetics do not tend to the halalness of the product. The government is expected to be increasingly concerned with the number of the circulation of cosmetic products, considering that Indonesia is the country with the largest Muslim population in the world, tightening halal products by issuing a mandatory halal logo on its products.
\end{abstract}

Keywords: Religiosity, purchase decision, halal cosmetics

\section{Introduction}

Halal refers to what is permissible, whereas haram refers to what is forbidden in Islam. Halal and haram laws are a part of Islam's overall legal system. When it comes to food, the phrase halal is assumed. However, this phrase has a broader meaning than just food [1]. Halal concerns all aspects of human life such as income, someone's attitude towards products, and religiosity [2]. The demand for halal products is not only for food but also for cosmetics [3]. Halal medicines and cosmetics have attained increasing awareness and demand of 2.4 billion Muslim consumers around the world. The global halal market is ready for expansion with a combined growth rate of $6.8 \%$ until 2024 [4]. Pigs, corpses, blood, human body parts, predators, reptiles, and insects are prohibited from being used in halal cosmetics. The cosmetic ingredients come from animals that must be slaughtered in accordance with Islamic law in order to be declared halal [1]. The halal cosmetic items must be labeled halal in accordance with the established label criteria. To aid consumers in making a decision and ingesting the food, the label must include a halal mark and accurately depict the product's components. Cosmetics products that have been registered their products to get the halal certificates in Indonesia are as seen in Table 1 below. 
Table 1. Cosmetics Halal in Indonesia

\begin{tabular}{clc}
\hline No & Brand & Halal Labeled \\
\hline. & & \\
\hline 1. & Wardah & 1998 \\
2. & Sariayu & 2012 \\
3. & Zoya & 2013 \\
4. & Forest Secret & 2014 \\
5. & BLP Beauty & 2016 \\
6. & ESQA & 2018 \\
7. & Amara & 2018 \\
8. & L’Oreal & 2018 \\
9. & Beauty Story & 2018 \\
10. & Make Over & 2018 \\
11. & Silky Girl & 2018 \\
12. & Safi & 2018 \\
13. & Olive Natural Skincare & 2018 \\
\hline
\end{tabular}

The halalness of these products is the right thing because it is related to Muslim worship and prayers. Consumers are expected to be provided with information about the halalness of the product, which if not done adequately will create bad satisfaction [5]. The halal label can give consumers with information and foster a sense of confidence. The purpose of the halal label on a product is to inform Muslim consumers who utilize halal products that the product is safe and can be trusted [6]. Halal certification on certain products assures Muslim customers that all materials and manufacturing methods are sharia-compliant [7]. Religion is a factor that influences people's everyday attitudes about product selection. This indicates that religiosity is linked to a way of life principle that is represented in society's and individuals' values and attitudes [8]. There have been several studies on religiosity [9, 10, 11, 8]. However, most research has only reached the intention to buy $[11,12,13,14]$. Several researchers found that religiosity affects purchasing decisions for halal products $[9,15]$. From the research that has been done, no one has revealed a person's religiosity towards the decision to buy halal cosmetics.

\section{Method}

This study was place from January to March 2020. Primary and secondary data were employed in this investigation. Primary data was collected using the survey approach, which involved randomly distributing questionnaires to students in three faculties at UMPP (regardless of age, gender, or class boundaries). The variable measurement scale on the questionnaire uses Likert scale. Secondary data was carried out by conducting literature studies from various available sources. The sampling procedure uses Non-Probability Sampling. The number of respondents used was 100 students from a population of 2.397 students. Data processing in this study used the SmartPLS 3.2.0 version software and Microsoft Excel 2013. The collected data was converted into csv extension using MS. Excel statistical analysis software then analyzed using SmartPLS 3.2.0 version software, which is expected to obtain accurate, complete, and comprehensive data analysis results.

The Partial Least Square-Structural Equation Model (PLS-SEM) is used in this study. SEM is a cross-sectional, linear, and general statistical modeling tool [16]. Factor analysis, path 
analysis, and regression are all included in this SEM. SEM is a statistical approach for developing and testing statistical models, most commonly causal models. SEM may estimate numerous relationship relationships between variables and depict the pattern of link between latent constructs and indicator variables. SEM can perform factor, regression, and path analysis simultaneously and can complete the analysis with a one-time estimate where the other is solved by multiple regression equations. It can be stated that SEM contains qualities that are more confirmatory than explanatory in nature. PLS-SEM is an alternative to SEM analysis that permits data that is not normally distributed to be used (SEM requires normally distributed data), but it may also be used with normally distributed data [16]. As a result, PLS-SEM is also known as a soft modeling technique with less severe requirements than SEM, such as measurement scale, sample size, and residual distribution. In PLS-SEM, the endogenous latent variable's variants are maximized by estimating the partial model relationship in the order of the usual least squares regression iteration, and the latent variable values are estimated using a linear combination of the indicator variables associated with the latent variable and treated as a substitute for the indicator variables. The main goal of PLS-SEM is to increase the variance of endogenous latent variables as described in [16]. A structural model analysis (inner model) can be performed using PLS-SEM, which shows the strength of the estimation between the latent or construct variables, as well as a measurement model evaluation analysis (outer model), which shows how the manifest variable represents the latent variable to be measured. The reflecting and formative models are evaluated separately in the measuring model evaluation. This research employs and evaluates a reflective model. The loading factor, composite reliability, average variance extracted (AVE), and Cronbach's alpha are all included while evaluating the outer model [17]. Evaluation of the inner model consists of two latent variables, namely religiosity and purchasing decisions. Each latent variable has a reflective indicator that reflects the variable. The analytical method is used to determine the overall direct and significant positive effect on exogenous latent variables, that is religiosity towards endogenous latent variables, that is purchasing decisions.

This research model uses an adaptation approach from [9] and [15] where religiosity is as $\mathrm{x} 1$ and purchasing decisions as $\mathrm{y} 2$. The construct that is built consists of religiosity which has 8 indicators [15] and purchasing decisions which have 6 indicators [11]. The research model is presented in Figure 1.

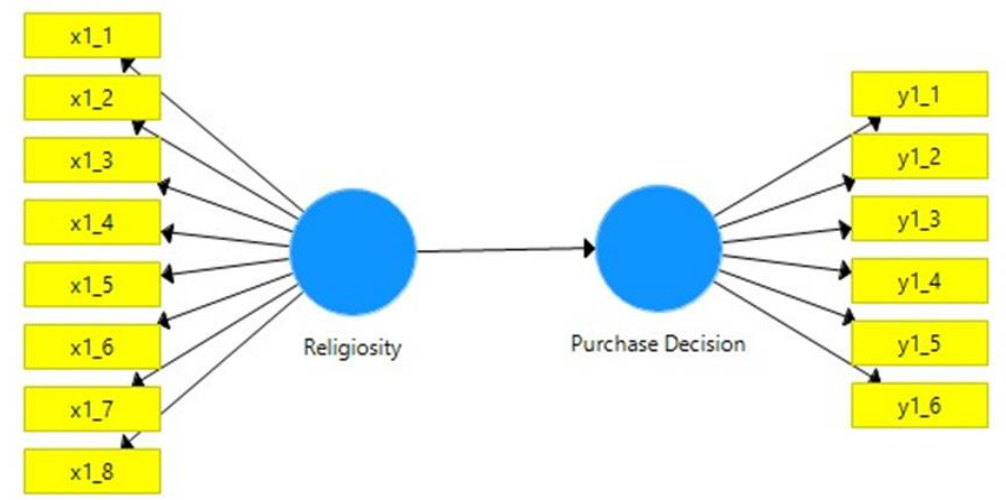

Fig. 1. Research Model 
The research hypothesis is compiled based on one thing that is a measure of religiosity towards purchasing decisions for halal products in youth. From Figure 1, the research hypothesis can be formulated as follows:

$\mathrm{H1}$ : religiosity has a significant effect on the purchase decision of halal cosmetics in youth

\section{Results and Discussions}

\subsection{PLS-SEM analysis in religiosity and purchase decisions}

The outer model and inner model are both evaluated when the PLS model is evaluated [18]. The outer model is a measuring model that is used to evaluate the model's validity and dependability. The measurement model parameters (convergent validity, discriminant validity, composite reliability, and Cronbach's alpha) were collected by the algorithm iteration process, including the R2 value as a parameter of the prediction model accuracy. The inner model is a structural model that predicts latent variable causality [18]

\subsection{Validity test}

The validity test assesses the strength of the association between the construct and the question items, as well as the relationship with other factors. The loading factor > 0.7, AVE > 0.5 , and cross-loading $>0.7$ in one variable is the rule of thumb that is commonly used to determine validity [19].

\subsection{Outer model}

In this study, the validity and reliability of the latent variable indicators of religiosity and purchasing decisions were carried out using the SmartPLS 3.2.0 software. Figure 2 shows the model output.

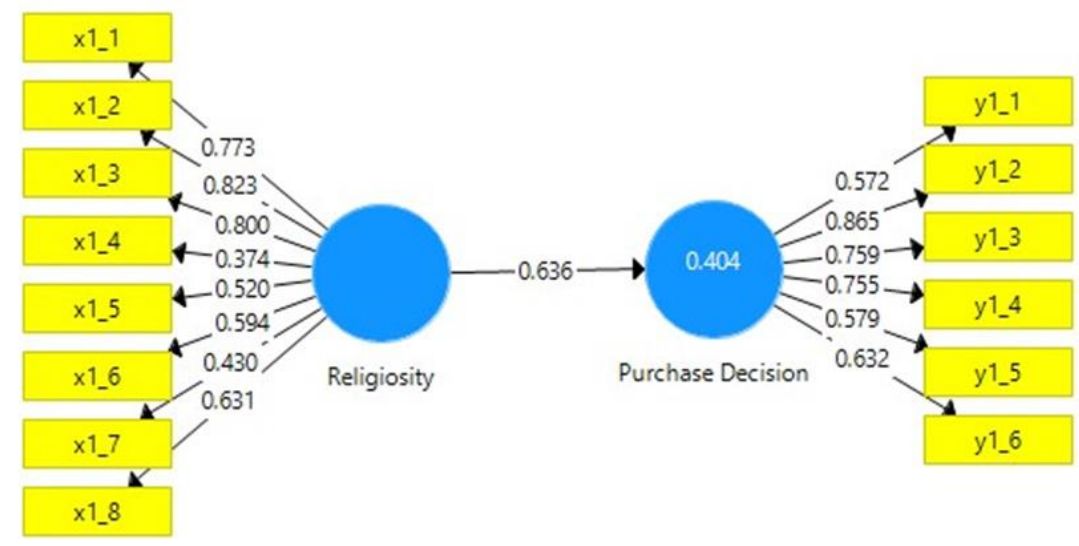

Fig. 2. Model Output 
From the result in Figure 2 shows that the loading factor for religiosity there are five indicators that have a value of $<0.7$, including x1_4 (0.374), x1_5(0.520), x1_6 (0.594), x1_7 (0.430), and x1_8 (0.631). Meanwhile, for purchasing decisions, three indicators have a value of <0.7, namely y1_1 (0.572), y1_5 (0.579) and y1_6 (0.632). That is, several indicators have a less strong correlation between the construct and the question items, while some correlate.

Based on the loading factor result in Figure 2, the indicators with a value of $<0.7$, that is $\mathrm{x} 1 \_4, \mathrm{x} 1 \_5, \mathrm{x} 1 \_6, \mathrm{x} 1 \_7, \mathrm{x} 1 \_8, \mathrm{y} 1 \_1, \mathrm{y} 1 \_5$ and $\mathrm{y} 1 \_6$ were removed from the model because they were not significant. Then the model is re-estimated again by removing these indicators. The results of the calculation are as shown in Figure 3.

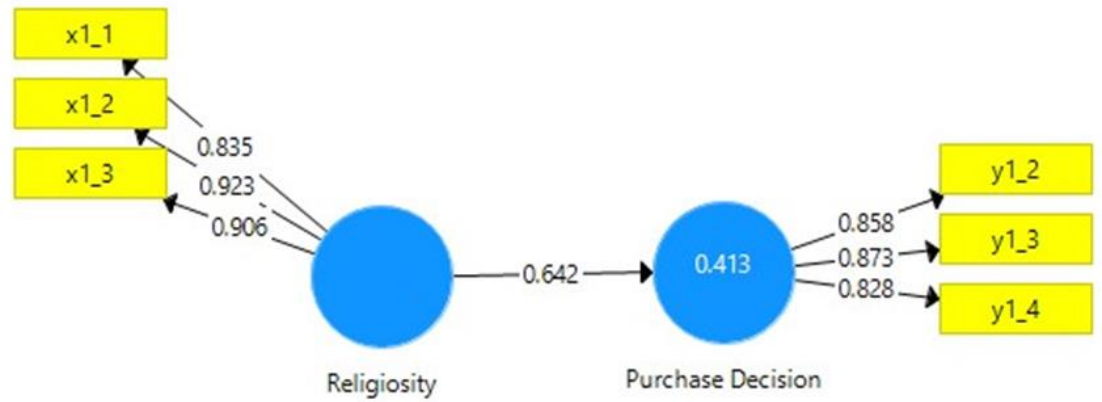

Fig. 3. Output Model After Change

From Figure 3 above, it can be seen that the loading factor $(\lambda)$ of the indicator value of each construct of religiosity and purchase decision has a value of $>0.7$, this means that it is valid to use. Construct reliability and validity show in Table 2.

Table 2. Construct reliability and validity

\begin{tabular}{lllll}
\hline & $\begin{array}{l}\text { Cronbach's } \\
\text { alpha }\end{array}$ & rho_A & $\begin{array}{l}\text { composite } \\
\text { reliability }\end{array}$ & $\begin{array}{l}\text { average variance extract } \\
\text { (AVE) }\end{array}$ \\
\hline purchase decision & 0.813 & 0.819 & 0.889 & 0.728 \\
Religiosity & 0.868 & 0.888 & 0.919 & 0.791 \\
\hline
\end{tabular}

From Table 2 it can be seen that the AVE value of each variable is valid because $>0.5$ is 0.728 for the purchasing decision variable and 0.791 for the religiosity variable. Discriminant validity show in Table 3.

Table 3. Discriminant Validity

\begin{tabular}{lll}
\hline & purchase decision & religiosity \\
\hline purchase decision & 0.853 & \\
Religiosity & 0.642 & 0.889 \\
\hline
\end{tabular}

The value of the correlation between the variable and the variable itself, as well as the value of the variable with other variables, is known as discriminant validity. The required correlation between the variable and the variable must be higher than the required correlation between the variable and other variables. Table 3 reveals that the purchasing decision variable's correlation 
value with the purchasing decision variable $(0.853)$ is higher than the purchasing decision variable's correlation value with the religiosity variable (0.642). Furthermore, the correlation coefficient between the religiosity variable and the religiosity variable $(0.889)$ is higher than the correlation coefficient between the purchase decision variable and religiosity $(0.642)$. There is no shortage of meaning. Cross loading show in Table 4.

Table 4. Cross Loading

\begin{tabular}{lll}
\hline & purchase decision & religiosity \\
\hline $\mathrm{x} 1 \_1$ & 0.468 & 0.835 \\
$\mathrm{x} 1 \_2$ & 0.631 & 0.923 \\
$\mathrm{x} 1 \_3$ & 0.596 & 0.906 \\
$\mathrm{y} 1 \_2$ & 0.858 & 0.564 \\
$\mathrm{y} 1 \_3$ & 0.873 & 0.582 \\
$\mathrm{y} 1 \_4$ & 0.828 & 0.493 \\
\hline
\end{tabular}

Cross loading is a correlation between indicators and variables. Table 4 shows that the indicators that measure the correlation variable are greater than the correlation indicators with other variables. The meaning, there is no lack.

\subsection{Reliability test}

The value of Cronbach's alpha and composite reliability must be greater than 0.7 [20]. AVE, Cronbach's Alpha, composite reliability show in Table 5.

Table 5. AVE, Cronbach's Alpha, Composite Reliability

\begin{tabular}{lllll}
\hline & $\begin{array}{l}\text { Cronbach's } \\
\text { alpha }\end{array}$ & rho_A & $\begin{array}{l}\text { composite } \\
\text { reliability }\end{array}$ & $\begin{array}{l}\text { average variance extract } \\
\text { (AVE) }\end{array}$ \\
\hline purchase decision & 0.813 & 0.819 & 0.889 & 0.728 \\
Religiosity & 0.868 & 0.888 & 0.919 & 0.791 \\
\hline
\end{tabular}

In table 5, the results of the analysis show that all latent variables have AVE, Cronbach's alpha, and composite reliability values above the set prerequisites, which is 0.7 , meaning that the measurement model is acceptable, valid, and reliable.

\subsection{Inner model}

The R-Square (R2) for the dependent variable is used to evaluate the structural model in PLS, while the path coefficients and t-statistic for each path are used to test the significance between variables in the model show in Table 6. The level of variation in changes in the independent variable versus changes in the dependent variable is measured by the $R 2$ value. The greater the R2 score, the better the research model's prediction model [18]. R2 values of 0.75 are considered high, 0.50 are considered moderate, and 0.25 are considered weak, according to the rule of thumb [20]. 
Table 6. R-square

\begin{tabular}{lll}
\hline & r square & Interpretation \\
\hline purchase decision & 0.413 & Moderate \\
\hline
\end{tabular}

Table 6 shows that the R2 value of the purchasing decision variable is 0.413 . This means that the purchasing decision variable is influenced by the religiosity of $41.3 \%$, while the remaining $58.7 \%$ is influenced by other variables such as halal certification, country of origin, and others.

By comparing the t-statistic with the t-table, hypotheses are tested by looking at the outcomes of bootstrapping on the path coefficients (1.96). If the t-statistic>t-table then the hypothesis (H1) is accepted. Tables 7 and 8 show the outcomes of data analysis with an alpha of $5 \%$.

Table 7. Path coefficient

\begin{tabular}{lll}
\hline & purchase decision & religiosity \\
\hline purchase decision & & \\
Religiosity & 0.642 & \\
\hline
\end{tabular}

The values in table 7 show that 0.642 are in the range of -1 to 1 . So, the direction of the relationship of religiosity to purchasing decisions is positive.

Table 8. t-statistic (bootstrapping)

\begin{tabular}{llllll}
\hline & $\begin{array}{l}\text { original } \\
\text { sample }\end{array}$ & $\begin{array}{l}\text { sample } \\
\text { mean }\end{array}$ & $\begin{array}{l}\text { standard } \\
\text { deviation }\end{array}$ & t-statistic & p-value \\
\hline religiosity to purchase decision & 0.642 & 0.518 & 0.319 & 2.013 & 0.045 \\
\hline
\end{tabular}

The t-statistic in Table 8 shows that the value 2013 is $>1.96$. So, the results of this study are significant. Hypothesis test result show in Table 9.

Table 9. Hypothesis Test Result

\begin{tabular}{llllll}
\hline Path & path coefficient & t-statistic & p-value & Hypothesis & Result \\
\hline $\begin{array}{l}\text { Religiosity } \rightarrow \text { Purchase } \\
\text { decision }\end{array}$ & 0,642 & 2.013 & 0.000 & Accepted & Significant \\
\hline
\end{tabular}

Based on the results of the evaluation of the inner model, the researcher concludes the research hypothesis. The results of hypothesis testing are as follows:

H1: There is an influence between religiosity on purchasing decisions

The results of the analysis as presented in Table 9 show that religiosity has a significant effect on purchasing decisions with a t-statistic of 2.013> 1.96 with a p-value or at a significance level of 0.000 , which means that the test results are $100 \%$ probable, then $\mathrm{H} 1$ is accepted. Indicators such as the 5 daily prayers, observing the fast-during Ramadan, and paying zakat all serve the reasons for a person to decide to buy halal cosmetics.

The results of this study are in line with research conducted by Bachleda which states that religiosity affects purchasing decisions for Moroccan women on Muslim clothing even though it has only a slight effect. Other characteristics, such as age, marital status, and education, may have higher value as a segmentation tool for women's apparel in Muslim nations, according to 
Bachleda's research. To put it another way, a Muslim woman's choice of clothing is not solely motivated by piety. This is confirmed by the results of this study. Respondents admit that the selection of halal cosmetics is not just about halal but also other factors such as compatibility with the respondent's skin type. Bachleda's research used regression as an investigative tool for research. Whereas in this study using SmartPLS. Research by Machali shows that religiosity has a direct effect on purchase decisions significantly. Customer behavior is influenced by consumer religiosity, according to the findings. Individuals who are deeply religious are more likely to be worried about halal meals and to make halal food purchases. The findings of this study back this up. The results of data analysis show that religiosity has a significant influence with a significance of 2.013 .

The present study had several limitations which might also inform future research. First, the number of respondents which is only 100 may not represent the number of users of halal cosmetics. Second, it is also deemed necessary to consider the age of the respondents.

\section{Conclusion}

The results of this research indicate that religiosity affects the purchase decision of halal cosmetics on youth. Even though religiosity affects the purchase decision but youth does not matter about the halalness of the cosmetics they buy due to the understanding that halal is only something that is eaten, they choose the products based on the ingredient (such as for sensitive skin).

\section{Acknowledgement}

The authors thank Universitas Muhammadiyah Pekajangan Pekalongan for the financial support of this research.

Author Contributions. Conceptualization (L.S, M.Y); Material research preparation (L.S, M.Y); Methodology (L.S, M.Y); Data collecting (L.S); Data analysis and visualization (L.S); Writing — original draft (L.S); Presentation (L.S).

\section{References}

[1] K. Sugibayashi, E. Yusuf, H. Todo, S. Dahlizar, P. Sakdiset, F. J. Arce and G. L. See, "Halal Cosmetics: A Review on Ingredients, Production, and Testing Methods," Journal Cosmetics, pp. 6, 37; doi:10.3390/cosmetics6030037, 2019.

[2] P. Hashim and M. Hashim, "A review of cosmetic and personal care products: Halal perspective and detection of ingredient," Pertanika Journal Science Technology, pp. 281-292, 2013.

[3] N. Sriminarti and L. Nora, "The Role of Product Knowledge and Attitudes toward Purchasing Intentions: the Moderating Effect of Religiosity on Halal Cosmetics," International Conference on Economics, Business and Economic Education, pp. 518-529, 2018.

[4] N. Trent, "Halal Cosmetics Market 2018-Industry Analysis, Share, Growth, Sales, Trends, Supply, Forecast to 2025," 17 September 2018. [Online]. Available: 
https://www.reuters.com/brandfeatures/venture-capital/article?id=52417. [Accessed 29 October 2019].

[5] S. Mohezar, S. Zailani and Z. Zainuddin, "Halal Cosmetics Adoption Among Young Muslim Consumers in Malaysia: Religiosity Concern," GJAT, pp. June 2016, Vol 6 Issue 1, ISSN: 2232 0474, e-ISSN: 2232-0482, 2016.

[6] H. Siala, "Religious influences on consumers' high-involvement purchasing decisions," Journal of Service Marketing, pp. 579-589, 2013.

[7] R. Yunos, N. Mansor and C. Mahmood, "Understanding Mechanisms to Promote Halal IndustryThe Stakeholders' Views," Social and Behavioral Science, pp. 160-166, 2014.

[8] S. Fam, D. Waller and B. Erdogan, "The Influence of Religion on Attitudes Towards The Advertising of Controversial Products," European Journal of Marketing, pp. 537-556, 2004.

[9] C. L. Bachleda, N. Hamelin and O. Benachour, "Does Religiosity Impact Moroccan Muslim Women's Clothing Choice?," Journal of Islamic Marketing, p. June, 2014.

[10] S. Yousaf and M. S. Malik, "Evaluating the influences of religiosity and product involvement level on the consumers," Journal of Islamic Marketing, p. DOI: 10.1108/17590831311329296, 2015.

[11] Y. Z. Basri and F. Kurniawati, "Effect of Religiosity and Halal Awareness on Purchase Intention Moderated by Halal Certification," International Conference on Economics, Management, and Accounting, pp. 592-607, 2019.

[12] A. Haque, N. Anwar, A. K. Tarofder, N. S. Ahmad and S. R. Sharif, "Muslim Consumers' Purchase Behavior Towards Halal Cosmetic Products in Malaysia," Management Science Letters, pp. 1305$1318,2018$.

[13] L. Mutmainah, "The Role of Religiosity, Halal Awareness, Halal Certification and Food Ingredients on Purchase Intention of Halal Food," IHTIFAZ: Journal of Islamic Economics, Finance and Banking, pp. 33-50, 2018.

[14] L. Nora and N. S. Minarti, "The Role of Religiosity, Lifestyle, Attitude as Determinant Purchase Intention," in The 2nd International Multidiciplinary Conference, Jakarta, 2016.

[15] M. M. Machali, L. A. Razak and R. Abdullah, "The Effect of Religiosity on Purchase Decision Towards Halal Foods with Awareness as Intervening Variable," https://www.researchgate.net/publication/288701861, 2014.

[16] J. Sarwono and U. Narimawati, Membuat Skripsi, Tesis, dan Disertasi dengan Partial Least Square SEM (PLS-SEM), Yogyakarta: Penerbit Andi, 2015.

[17] I. Ghozali, Aplikasi Analisis Multivariate dengan Program IBM SPSS. 23, Semarang: Universitas Diponegoro, 2015.

[18] W. Abdillah and J. M. Hartono, Partial Least Square (PLS) alternatif Structural Equation Modeling (SEM) dalam Penelitian Bisnis, Yogyakarta: Penerbit Andi, 2015.

[19] W. W. Chin, "Modern Method for Business Research: Chapter Ten, The Partial Least Square $\begin{array}{llll}\text { Approach to } & \text { Structural } & \text { Equation } & \text { Modeling }\end{array}$ https://www.researchgate.net/publication/232569511, pp. 295-336, 1998.

[20] J. F. Hair, M. Sarstedt and C. M. Ringle, " PLS-SEM: Indeed a Silver Bullet," The Journal of Marketing Theory and Practice, pp. 139-151, 2011. 